\title{
COMMENTARY
}

\section{Activated protein C for H1N1 influenza? More work to do!}

\author{
Steven P LaRosa* \\ See related research by Schouten et al., http://ccforum.com/content/14/2/R65
}

\begin{abstract}
An animal model of $\mathrm{H} 1 \mathrm{~N} 1$ influenza demonstrates that this infection is associated with pulmonary and systemic activation of coagulation and impairment of fibrinolysis in addition to systemic inflammation and intense neutrophil influx into the lung. Activated protein $\mathrm{C}$ attenuates coagulation activation and restores fibrinolytic capacity but has little effect on inflammation or survival from this infection. This animal model points to a profound inflammatory state developing in $\mathrm{H} 1 \mathrm{~N} 1$ infection that impacts mortality. Additional modifications to the model and the type and amount of activated protein $\mathrm{C}$ dosing will provide the data to determine the possible use of activated protein $\mathrm{C}$ as a therapy in human H1N1 infection.
\end{abstract}

In 2009 the seasonal influenza virus was replaced with a pandemic H1N1 infection strain (swine flu). Since that time, numerous reports have surfaced of severe disease occurring and resulting in acute lung injury and mortality. Treatment of this infection has involved oseltamavir and supportive care. A logical next step would be to find an adjuvant agent that could be of benefit in severe disease. To discover this agent, one must first understand the pathogenesis of this unique virus.

In the previous issue of Critical Care, Schouten and colleagues attempt to build on the knowledge gained about the pathogenesis of H1N1 in a lethal mouse model [1]. These authors ask two questions. Does viral pneumonia due to H1N1 cause sytemic and pulmonary activation of coagulation and inhibition of fibrinolysis in the lungs similar to what is known to occur in communityacquired bacterial pneumonia and acute respiratory

*Correspondence: slarosa@lifespan.org

Division of Infectious Disease, Rhode Island Hospital, Alpert School of Medicine, Brown University, 593 Eddy Street, Providence, RI 02903, USA distress syndrome? If so, does activated protein C (APC) - a molecule with anticoagulant, anti-inflammatory and profibrinolytic properties - abrogate this response and improve outcome, as is suggested by its effects in patients with sepsis due to community-acquired pneumonia [2]?

The results of Schouten and colleagues' study indicate that activation of coagulation and impairment of fibrinolysis does in fact occur during H1N1 infection. They also corroborate the findings of intense neutrophil influx in the lung, prolonged cytokine storm and diffuse alveolar damage as key components of the pathogenesis of the infection [3]. APC was able to decrease coagulation activation and restore normal fibrinolysis compared with placebo but had marginal effects on cytokine levels, pulmonary neutrophil influx and outcome.

The results from this animal study add to the evidence that coagulation inhibition per se does not improve outcome in acute lung injury. A randomized, placebocontrolled trial of recombinant human APC in 75 patients with acute lung injury without sepsis demonstrated no benefit of APC with respect to ventilator-free days, mortality or lung injury score [4]. A trial of a recombinant tissue factor pathway inhibitor in patients with severe community-acquired pneumonia demonstrated no benefit (Wunderiak R, et al.,unpublished data).

A possible downside to thrombin inhibition by anticoagulation agents is the loss of the ability to wall off infection through fibrin formation. Fortunately, APC led to lower viral load in the lungs. Additionally, inhibition of thrombin formation could prevent the activation of thrombin activatable fibrinolysis inhibitor. Activated thrombin activatable fibrinolysis inhibitor inhibits the chemotactic factors C3a and C5a, which could be important for prevention of influx of leukocytes into the lung [5]. As the authors of the current study mention, mutant variants of APC with anti-inflammatory properties and little anticoagulant activity could be examined in future animal studies.

The lack of effect of APC on cytokine production and neutrophil influx that is prominent in $\mathrm{H} 1 \mathrm{~N} 1$ merits discussion. The current study's authors showed that APC had no effect on cytokine elaboration or pulmonary 
neutrophil influx in a Pseudomonas aeruginosa pneumonia model and in an endotoxin challenge model in rats $[6,7]$. In vitro models have demonstrated an inhibitory effect of APC on cytokine effect with much higher concentrations of APC relative to the levels achieved in this study [8]. In both a human and a sheep pulmonary endotoxin study, recombinant human APC given as a continuous infusion of $24 \mu \mathrm{g} / \mathrm{kg} /$ hour was able to decrease the infiltration of neutrophils into the lung $[9,10]$. In human septic patients and in an intravenous endotoxin challenge model in healthy human volunteers, no anti-inflammatory effects were observed with this dosing strategy [11,12]. These data would suggest that the anti-inflammatory effects of APC vary by species, by type of infectious challenge, by means of APC dosing and by blood concentrations, such that more information needs to be learned with respect to optimized dosing in $\mathrm{H} 1 \mathrm{~N} 1$ infection. Future animal studies with the previously mentioned APC variants with minimal anticoagulant effects would allow the authors to push the blood concentration for determination of the maximal anti-inflammatory effect.

The absence of a benefit in terms of survival with APC treatment in this murine model of H1N1 infection does not necessarily predict a lack of benefit in human H1N1 infection. This model was quite severe with $100 \%$ lethality, while mortality in human $\mathrm{H} 1 \mathrm{~N} 1$ infection is less than $20 \%$ in severe cases $[13,14]$. The mice were young, healthy and of normal weight, which does not mimic the clinical situation in humans. Oseltamavir was not given in this model, which could affect the treatment response to APC. Upwards of $30 \%$ of human patients with H1N1 develop bacterial pneumonia and severe sepsis in which recombinant human APC may still be beneficial [3]. Severe human H1N1 infection is complicated by shock in 30 to $60 \%$ of cases and by renal failure in $22 \%$ of cases $[13,14]$. This animal model did not monitor organ dysfunction, which APC may prevent through PAR-1 signaling [15].

In summary, the jury is still out regarding whether APC could potentially play a future role in the management of $\mathrm{H} 1 \mathrm{~N} 1$ infection. Future experiments will need to include mice and other species of different ages, different infecting doses of H1N1, concomitant oseltamavir treatment, monitoring and evaluation of hemodynamic and nonpulmonary organ function, and different dosages and means of administration of APC and APC variants.

\section{Abbreviations}

APC, activated protein C.

\section{Competing interests}

SPL is a former employee of Eli Lilly and company, the maker of recombinant human activated Protein $C$.

Published: 18 May 2010
References

1. Schouten M, van der Sluijs KF, Gerlitz B, Grinnell BW, Roelofs JJTH, Levi MM, van't Veer C, van der Poll T: Activated protein C ameliorates coagulopathy but does not influence outcome in lethal H1N1 influenza: a controlled laboratory study. Crit Care 2010, 14:R65.

2. Laterre PF, Garber G, Levy H, Wunderink R, Kinasewitz GT, Sollet JP, Maki DG, Bates B, Yan SCB, Dhainaut JF: Severe community-acquired pneumonia as a cause of severe sepsis: data from the PROWESS study. Crit Care Med 2005, 33:952-961.

3. To KKW, Hung IFN, Li IWS, Lee KL, Koo CK, Yan WW, Liu R, Ho KY, Chu KH, Watt CL, Luk WK, Lai KY, Chow FL, MokT, Buckley T, Chan JFW, Wong SSY, Zheng B, Chen H, Lau CCY, Tse H, Cheng VCC, Chan KH, Yuen KY: Delayed clearance of viral load and marked cytokine activation in severe cases of pandemic H1N1 2009 influenza virus infection. Clin Infect Dis 2010, 50:850-859.

4. Liu KD, Levitt J, Zhuo H, Kallet R, Brady S, Steingrub J, Tidswell M, Siegel M, Soto G, Peterson MW, Chesnutt MS, Phillips C, Weinacker A, Thompson BT, Eisner MD, Matthay MA: Randomized clinical trial of activated protein C for the treatment of acute lung injury. Am J Respir Crit Care Med 2008, 178:618-623.

5. Mosnier LO, Yang XV, Griffin JH: Activated protein C mutant with minimal anticoagulant activity, normal cytoprotective activity, and preservation of thrombin activable fibrinolysis inhibitor-dependent cytoprotective functions. J Biol Chem 2007, 282:33022-33033.

6. Choi G, Hoffstra JJ, Roelofs JJTH, Florquin S, Bresser P, Levi M, van der poll T, Schultz MJ: Recombinant human activated protein $C$ inhibits local and systemic activation of coagulation without influencing inflammation during Pseudomonas aeruginosa pneumonia in rats. Crit Care Med 2007, 35:1362-1368

7. Choi G, Vlaar APJ, Schouten M, van't Veer C, van der Poll T, Levi M, Schultz MJ: Natural anticoagulants limit lipopolysaccharide-induced pulmonary coagulation but not inflammation. Eur Respir J 2007, 30:423-428.

8. White B, Schmidt M, Murphy C, Livingstone W, O'Toole D, Lawler M, O'Neill L, Kelleher D, Schwarz HP, Smith OP: Activated protein C inhibits lipopolysaccharide-induced nuclear translocation of nuclear factor kb (NF-kb) and tumour necrosis factor a production in the THP-1 monocytic cell line. Br J Hematol 2000, 110:130-134.

9. Nick JA, Coldren CD, Geraci MW, Poch KR, Fouty BW, O'Brien J, Gruber M, Zarini S, Murphy RC, Kuhn K, Richter D, Kast KR, Abraham E: Recombinant human activated protein $C$ reduces human endotoxin-induced pulmonary inflammation via inhibition of neutrophil chemotaxis. Blood 2004, 104:3878-3885

10. Waerhaug K, Kuklin VN, Kirov MY, Sovershaev MA, Langbakk B, Ingebresten OC, Ytrehus K, Bjertnaes L: Recombinant human activated protein C attenuates the endotoxin-induced lung injury in awake sheep. Crit Care 2008, 12:R104.

11. Bernard GR, Vincent JL, Laterre PF, LaRosa SP, Dhainaut JF, Lopez-Rodriguez A, Steingrub JS, Garber GE, Helterbrand JD, Ely EW, Fisher Jr CJ: Efficacy and safety of recombinant human activated protein $\mathrm{C}$ for severe sepsis. N Engl J Med 2001, 344:699-709.

12. Kalil AC, Coyle SM, Um JY, LaRosa SP, Turlo MA, Calvano SE, Sundin DP, Nelson DR, Lowry SF: Effects of drotrecogin alfa (activated) in human endotoxemia. Shock 2004, 21:222-229.

13. Kumar A, Zarychanski R, Pinto R, Cook DJ, Marshall J, Lacroix J, Stelfox T, Bagshaw S, Choong K, Lamontagne F, Tugeon AF, Lapinsky S, Ahern SP, Smith OR, Siddiqui F, Jouvet P, Khwaja K, Mclntyre L, Menon K, Hutchison J, Hornstein D, Joffe A, Lauzier F, Singh J, Karachi T, Wiebe K, Olafson K, Ramsey C, Sharma S, Dodek P, et al:: Critically III patients with 2009 influenza A (H1N1) infection in Canada. JAMA 2009, 302:1872-1879.

14. Rello J, Rodriguez A, Ibanez P, Socias L, Cebrian J, Marques A, Guerrero J, Ruiz-Santana S, Marquez E, Del Nogal-Saez F, Alvaez-Lerma F, Martinez S, Ferrer M, Avellanas M, Granada R, Maravi-Poma E, Albert P, Sierra R, Vidaur L, Ortiz P, Prieto del Portillo I, Galvan B, Leon-Gil C: Intensive care adult patients with severe respiratory failure caused by Influenza $A(H 1 N 1) v$ in Spain. Crit Care 2009, 13:R148

15. Gupta A, Gerlitz B, Richardson MA, Bull C, Berg DT, Syed S, Galbreath EJ, Swanson BA, Jones BE, Grinnell BW: Distinct functions of activated protein C differentially attenuate acute kidney injury. J Am Soc Nephrol 2009, 20:267-277.

doi:10.1186/cc8994

Cite this article as: LaRosa SP: Activated protein C for H1N1 influenza? More work to do! Critical Care 2010, 14:156. 